\title{
OIL AND GAS DEVELOPMENT IN DISPUTED WATERS UNDER UNCLOS
}

\author{
Constantinos Yiallourides*
}

\begin{abstract}
Maritime delimitation is crucial in determining which coastal States may exercise control and jurisdiction over certain hydrocarbon deposits. Although international law has recently become more precise on the matter, boundary disputes are frequently resolved only after several or even many years. Even while coastal States are in a deadlock over delimitation issues, the need to explore and exploit the disputed areas' resources remains imperative for reasons of energy security, social welfare and economic development. Thus, the question arises as to the rights and obligations of coastal States with respect to the development of natural resources in areas subject to overlapping claims.
\end{abstract}

Against this background, the paper examines the relevant provisions of the 1982 United Nations Convention on the Law of the Sea, international jurisprudence and State practice. The central argument advanced is that in the absence of an agreed boundary or a provisional cooperative agreement, none of the States concerned operates legitimately in unilaterally undertaking petroleum operations in the disputed area, including seismic surveys, should the conduct of such operations prove to aggravate the dispute. Finally, this paper considers the practical implications of the aforementioned legal position on the development of hydrocarbon resources in areas subject to overlapping maritime claims.

\section{A. INTRODUCTION}

It would not be unreasonable to say that most of the world's maritime boundary conflicts have been resource-induced, most commonly by the known or suspected presence of mineral and fossil-fuel deposits lying in areas over which two or more coastal States may claim control and jurisdiction. ${ }^{1}$ Indeed, given that each square metre of subsea territory may potentially hold energy resources worth millions of dollars, the precise location of the boundary would not be a matter of indifference to either of the coastal neighbours affected. It follows that maritime delimitation is crucial in determining which State controls the said resources. However, even though international law has become more precise on the issue in recent times, experience shows that boundary disputes are not infrequently resolved only after several years. ${ }^{2}$ It is understandable that, although the exact location of the boundary remains uncertain, the need

\footnotetext{
* Doctoral Researcher at the Centre for Energy Law, School of Law, University of Aberdeen. The author would like to express his special appreciation and thanks to his supervisors Professor John Paterson and Mr Scott Styles for their aspiring guidance and constructive criticism during his studies in Aberdeen.

${ }^{1}$ Jan Paulsson, 'Boundary Disputes Into The Twenty-First Century: Why, How...And Who?' (2001) 95 ASIL $122,123$.

${ }^{2}$ Yoshifumi Tanaka, Predictability and Flexibility in the Law of Maritime Delimitation (Hart Publishing 2006) 125, 129 -130; Judge Peter Tomka, 'Speech to the Sixth Committee of the UN General Assembly' (2 November 2012) <www.icj-cij.org/presscom/files/6/17156.pdf> accessed 30 December 2015.
} 
for exploiting mineral resources of an overlapping area remains imperative for the States affected.

It is for this reason that the legal regime governing the economic exploitation of areas subject to overlapping claims has for many years been a source of discussion and extensive research. Indeed, in the past several decades many leading international law experts such as Professors Lagoni, ${ }^{3}$ Miyoshi, ${ }^{4}$ Fox,${ }^{5}$ and Churchill ${ }^{6}$ have sought to determine the rights and duties of States, pending the final settlement of their boundaries and the possible interim solutions. Articles 74(3) and 83(3) of the 1982 United Nations Convention on the Law of the Sea (hereafter, UNCLOS or 1982 Convention), ${ }^{7}$ the only provisions that deal directly with the duties of States 'pending agreement' on delimitation, do not contain any express rules against the prohibition of any particular oil and gas activities in the disputed area. Instead, they impose an open-ended obligation on States to refrain from any acts that would 'jeopardize or hamper' the final delimitation agreement. Yet, the question about what kind of economic activities would have the effect of jeopardising or hampering the final delimitation agreement remains critically unanswered.

One of the main findings of previous studies with respect to petroleum operations in disputed areas is that States are under an international obligation to refrain from undertaking any acts related to drilling of wells, establishment of installations and appropriation of petroleum. ${ }^{8}$ This obligation seems to derive from conventional law, such as UNCLOS, and is also said to be reflected in customary international law as a general obligation of 'mutual restraint'. On the other hand, seismic exploration surveys have traditionally been considered as being 'legally permissible', even when conducted without the other interested parties' consent. ${ }^{9}$ Interestingly, one of the main reasons offered for the above distinction is that, whereas the former acts can have a permanent physical impact on the marine environment of the disputed area, seismic surveys, due to their transitory character, cannot have such effect.

What is rather questionable, however, is how this rule has come to be and whether it is consistent with the rules of present international law. The main reason underlying this question

\footnotetext{
${ }^{3}$ Rainer Lagoni, 'Interim Measures Pending Maritime Delimitation Agreements' (1984) 78(2) AJIL 345.

${ }^{4}$ Masahiro Miyoshi, 'The Basic Concept of Joint Development of Hydrocarbon Resources on the Continental Shelf' (1988) 3(1) IJECL 1.

${ }^{5}$ Hazek Fox and others (eds), Joint Development of Offshore Oil and Gas (BIICL 1989).

${ }^{6}$ Robin Churchill and Geil Ulfstein, Marine Management in Disputed Areas: The Case of the Barents Sea (Routledge 1992).

${ }^{7}$ United Nations Convention on the Law of the Sea (adopted 10 December 1982, entered into force 16 November 1994) 1833 UNTS 3.

${ }^{8}$ Lagoni (n 3) 362-366; Miyoshi (n 4) 10-11; Fox and others (n 5) 35; Churchill and Ulfstein (n 6) 87-88.

9 ibid.
} 
is the fact that most of the initial studies on the topic were largely based on examples from case law that predated the 1982 Convention, such as the North Sea Delimitation Cases of 1969, ${ }^{10}$ the Aegean Sea Case of 1976, ${ }^{11}$ and the Fisheries Jurisdiction Case of $1974 .{ }^{12}$ Given that UNCLOS only came into force in 1994, it follows that most, if not all, of these cases had been adjudicated on the basis of the 1958 Continental Shelf Convention (the 1958 Convention). ${ }^{13}$ However, the 1958 Convention did not contain any rules or provisions dealing with the rights and obligations of States pending delimitation. Such provisions in the form of Articles 74(3) and 83(3), for example, were only introduced by the 1982 Convention: that is, 24 years later. Nor did State practice regarding offshore petroleum activities provide much evidence in this regard, largely because of the limited deep-sea drilling capabilities prior to the 70s or early 80 s. ${ }^{14}$ As a consequence, the status of knowledge with regard to the duties of States pending delimitation was rather limited before UNCLOS came into force. Indeed, in the words of Churchill and Ulfstein, 'it is not clear what activities are caught by this provision. The basic rule itself will be strengthened if or when the 1982 UN Convention on the Law of the Sea enters into force'. 15

Therefore, while by no means irrelevant, these early case-studies cannot be said to form the best set of evidence in terms of determining the substantial content of States' obligations pending delimitation under present international law. Rather, any conclusion deriving from these initial studies needs to be critically reviewed in the light of the more recent case law and State practice. In stark contrast to this important realisation, it can be observed that even the most recent studies on the topic tend to re-cite the conclusions of previous scholars without attempting to understand the evidence on which these conclusions were based. ${ }^{16}$

Notwithstanding their manifest political nature, maritime disputes, ie disputes pertaining to the use of the oceans and the seas, are primarily a legal matter governed by the rules and principles of the law of the sea which operates within and draws authority from the overall normative framework of public international law. As a consequence, maritime disputes must be reviewed against the overarching framework of public international law at large. Key

\footnotetext{
${ }^{10}$ North Sea Continental Shelf Cases (Germany/Denmark; Germany/Netherlands) (Judgment) [1969] ICJ Rep 3 (North Sea CS Cases).

${ }_{11}$ Aegean Sea Continental Shelf (Greece/Turkey) (Interim Measures) [1976] ICJ Rep 3 (Aegean Sea CS Case).

${ }^{12}$ Fisheries Jurisdiction Case (United Kingdom/Iceland) (Merits) [1974] ICJ Rep 3.

${ }^{13}$ Convention on the Continental Shelf (adopted 29 April 1958, entered into force 10 June 1964) 499 UNTS 311 (1958 Convention).

${ }^{14}$ For a discussion, see Hance D Smith, ‘The Problems of Hydrocarbon Extraction' (1977) 4(6) MPM 351.

${ }^{15}$ Referring to Articles 74(3) and 83(3) of UNCLOS, Churchill and Ulfstein (n 6) 88.

${ }^{16}$ Robert Beckman and others (eds), Beyond Territorial Disputes in the South China Sea: Legal Frameworks for the Joint Development of Hydrocarbon Resources (Edward Elgar 2013) 102-103.
} 
is examining the different 'sources' from which the rules of international law, including those relevant to the law of the sea, may be extracted and analysed. ${ }^{17}$

For the reasons explained above, the aim of this paper is to shine some fresh light on the evolution of the aforementioned rule in order to ascertain its validity and consistency with the present international law. In doing so, the present paper adopts a more holistic approach: taking into account both previous studies as well as recent examples from case law and State practice. The central argument advanced is that, in the absence of an agreed boundary or a provisional cooperative agreement, none of the interested States would operate legitimately in undertaking unilateral petroleum activities in areas subject to dispute, should the conduct of such activities prove to aggravate the dispute.

In addition to the above, even though a considerable amount of research has been devoted to the legal duties of States pending delimitation and the possible interim solutions (joint development schemes, for instance), rather less attention has been paid to the practical consequences or implications of said legal duties. In other words, while the majority of authors simply restate the obligations of States in the absence of an agreed boundary and then move on to propose possible solutions, there has been little discussion about how exactly these conflicts impact on oil and gas development in disputed areas. Nevertheless, as a prerequisite for offering a solution, it is necessary first of all to understand the problem, not least from its legal perspective, but also from its commercial and geo-political perspectives. Therefore, this paper also highlights the commercial and political considerations inherent to the exploration and exploitation of disputed subsea mineral and fossil-fuel deposits. This will not only contribute to the overall and in-depth understanding of the various problems associated with the exploitation of disputed natural resources but more importantly, it will provide some clarity on where a possible solution to unlock these practical hurdles might lie.

\footnotetext{
${ }^{17}$ According to Article 38 of the Statute of the International Court of Justice, which is universally accepted as the most authoritative statement of the formally recognised sources of international law, in deciding international disputes brought to it, the Court shall apply: a) international conventions; b) international custom; c) the general principles of law; and e) judicial decisions and the teachings of the most highly qualified publicists. Statute of the International Court of Justice (1945) 39 AJIL Supp 215.
} 


\section{B. CONTESTED WATERS: MARITIME SPACES UNDER OVERLAPPING SOVEREIGN CLAIMS}

Under both conventional ${ }^{18}$ and customary ${ }^{19}$ international law, all coastal States are entitled to a continental shelf area, extending to at least 200 nautical miles (nm) from their coastal baselines, over which they enjoy 'sovereign rights' for the purpose of exploring and exploiting their subsea natural resources. These rights exist ipso facto and $a b$ initio $^{20}$ in the sense that no special legal acts or declarations need to be performed for such rights to be enacted. ${ }^{21}$ More importantly, these rights are 'exclusive' in the sense that if a coastal State chooses not to explore or exploit the continental shelf areas appertaining to it, no one else may do so without its express consent. ${ }^{22}$ Likewise, all coastal States are entitled to an Exclusive Economic Zone $(\text { EEZ })^{23}$ extending up to $200 \mathrm{~nm}$ from the coastal baselines over which they also enjoy sovereign rights for the purpose of exploring and exploiting their offshore natural resources, though this zone applies both to non-living, such as oil and gas, and living resources, such as fisheries. ${ }^{24}$ Finally, it is important to note that by virtue of their sovereign rights over their offshore mineral resources, both in the context of the EEZ and the continental shelf, coastal States also enjoy the exclusive right and jurisdiction to authorise geophysical surveys, ${ }^{25}$ as well as construct, operate and use installations and any other structures necessary for the exploration and exploitation of their natural resources. ${ }^{26}$

If a coastal State's right to claim a continental shelf, and/or an EEZ, does not overlap with a similarly exercisable right by a neighbouring State, the establishment of such zones may be effected unilaterally pursuant to the aforementioned rules of international law. ${ }^{27}$ If, however, the exercise of a coastal State's entitlement to the above maritime zones interferes with another State's similar entitlement in the same area, when, for example, the distance between the two

\footnotetext{
${ }^{18}$ Art 6, 1958 Convention; Arts 76 and 77, UNCLOS.

${ }^{19}$ North Sea CS Cases (n 10) para 19; Continental Shelf Case (Libya/Malta) [1985] ICJ Rep 15 para 39.

${ }^{20}$ North Sea CS Cases (n 10) para 19.

${ }^{21}$ ibid; David M Ong, 'Joint Development of Common Offshore Oil and Gas Deposits: "Mere" State Practice or Customary International Law?’ (1999) 93 (4) AJIL 771, 775.

${ }^{22}$ Art 77 (3), UNCLOS; Article 81 of UNCLOS grants coastal States the 'exclusive' right to authorize and regulate drilling on the continental shelf for all purposes; North Sea CS Cases (n 10) para 19.

${ }^{23}$ Art 57, UNCLOS.

${ }^{24}$ ibid. See also David J Attard, The Exclusive Economic Zone in International Law (Clarendon Press 1987) 5461.

${ }^{25}$ Art 56(1)(b)(ii) and 253, UNCLOS.

${ }^{26}$ Art 60 and 80 mutandis mutandis UNCLOS; Attard (n 24) 54-61.

${ }^{27}$ Victor Prescott and Clive Schofield, Maritime Political Boundaries of the World (2nd edn, MN 2005) 2; Myron H Nordquist and others (eds), United Nations Convention on the Law of the Sea, 1982: A commentary (Vol 2, Martinus Nijhoff 1985) 813 (Virginia Commentary).
} 
coastal States is less than $400 \mathrm{~nm}$, the process of maritime delimitation must be initiated as a means to determine where the dividing line between the two entitlements lies. ${ }^{28}$

The above definitional framework gives rise to an important distinction: the entitlement to a certain maritime area and the delimitation of that area between two, or more, adjacent or opposite coastal States. ${ }^{29}$ On the one hand, delimitation is a process which has a de facto subsidiary nature in the sense that it becomes necessary only once overlapping claims have occurred. ${ }^{30}$ On the other hand, the inherent nature of a coastal State's sovereign rights over its continental shelf means that this maritime area appertains to the State, regardless of whether it has been previously delimited or not. ${ }^{31}$ Paragraph 10 of Article 76 of UNCLOS concerning the definition of the continental shelf provides that, 'the provisions of this article are without prejudice to the question of delimitation of the continental shelf between States with opposite or adjacent coasts'. Therefore, as the International Court of Justice (ICJ) held in its Libya/Malta judgement, the questions of entitlement to continental shelf, on the one hand, and of delimitation of continental shelf on the other, 'are not only distinct but are also complementary'. ${ }^{32}$ Indeed, the process of delimitation, 'cannot constitute, or derogate from, the general entitlement under international law of each state to its portion of the continental shelf ${ }^{33}$ Accordingly, maritime delimitation is not used to determine what a State's entitlement to a continental shelf, and/or an EEZ is, but rather to draw a dividing line 'between areas which already appertain [in principle] to one or other of the States affected' ${ }^{34}$

In light of this consideration, it seems that in the absence of such 'dividing line', a legal presumption exists that each of the States concerned is, in principle, entitled to, and may validly claim the relevant rights in the area in question. ${ }^{35}$ Indeed, as Professor Miyoshi explains:

In as much as a State has sovereign rights over its continental shelf under customary international law... the other State also has [equally] its sovereign rights over its share... even if it does not explore the continental shelf or exploit its natural resources. ${ }^{36}$

\footnotetext{
${ }^{28}$ Douglas M Johnston and Philip M Saunders, Ocean Boundary Making: Regional Issues and Developments (Croom Helm 1988) 17; Tanaka (n 2) 7-8.

29 Daniel P O'Connell (ed), The International Law of the Sea (Vol 1, Clarendon Press 1982) 691-692.

${ }^{30}$ Gerard J Tanja, The Legal Determination of International Maritime Boundaries (Kluwer Law and Taxation Publishers 1990) xvi.

31 Churchill and Ulfstein (n 6) 86.

${ }^{32}$ Libya/Malta Case (n 19) paras 27, 28.

33 O'Connell (n 29) 692.

${ }^{34}$ North Sea CS Cases (n 10) paras 18, 20.

35 Ong (n 21) 773.

36 Miyoshi (n 4) 13.
} 
In other words, both states claim the same exploration and exploitation rights over the same geographic area, yet, pending the final resolution of the dispute, the 'exclusive' holder of these rights remains unknown. It is clear that the alleged rights cannot be said to be exclusive to both states concerned. ${ }^{37}$ Moreover, as the ICJ observed, 'evidently any dispute about boundaries must involve that there is a disputed marginal or fringe area, to which both parties are laying claim' ${ }^{38}$ In this case, it is presumed that each bona fide claim is legally valid and that each of the claimants is legally entitled to claim the relevant rights to the area in question. ${ }^{39}$ Yet, it is one thing to be 'entitled to claim' and it is another to be 'entitled to exercise' the asserted rights. Indeed, as it will be seen further below, albeit legally entitled to continental shelf and EEZ rights, none of the disputing parties may, from a legal point of view, unilaterally exercise these rights, prior to the final settlement of the dispute. This is because, though both claimants have an inherent right to explore and exploit the given area, at the same time each claimant can preclude one another from embarking upon such activities in the area in question.

Be that as it may, the economic and political implications for the States concerned are enormous. As Ong, a leading expert on the law of the sea, observes, 'with regard to seabed resources which could prove crucial to the well-being and political stability of coastal states, extensive overlapping claims forestall development while boundaries remain uncertain'. ${ }^{40}$ Given that maritime delimitation, whether by agreement or by reference to third-party adjudication, has historically proven to be an extremely time-consuming process, ${ }^{41}$ the interested States may not be able to afford to suspend the economic exploitation of the disputed areas pending delimitation. ${ }^{42}$ It is understandable that, even while the boundary remains uncertain, the need for exploring and receiving the economic benefits from disputed natural resources remains imperative for economic, energy-security and political reasons. Clearly, there is a clash between the need for utilizing the disputed natural resources and the legal requirement not to infringe each State's exclusive sovereign rights on the area in question.

\footnotetext{
${ }^{37}$ Fox and others (n 5) 46.

${ }^{38}$ North Sea CS Cases (n 10) para 20.

${ }^{39}$ Ong (n 21) 773, 774.

40 ibid.

${ }^{41}$ Lagoni (n 3) 346.

${ }^{42}$ Beckman and others (n 16) 100.
} 


\section{ASSESSING THE LEGALITY OF OIL AND GAS ACTIVITIES IN DISPUTED WATERS UNDER UNCLOS}

\section{Introduction to Articles 74(3) and 83(3) of UNCLOS}

The starting point in any question concerning the legal treatment of offshore petroleum exploration and exploitation activities must be UNCLOS which is the primary regulatory instrument with respect to the international uses of the oceans and the seas. However, the only provision in UNCLOS that directly applies to the duties of States affected by overlapping maritime claims is paragraph 3 found both in Article 74 concerning delimitation of the EEZ and Article 83 concerning delimitation of the continental shelf. Paragraph 3 in both Articles reads as follows:

Pending [delimitation]... the States concerned, in a spirit of understanding and cooperation, shall make every effort to enter into provisional arrangements of a practical nature and, during this transitional period, not to jeopardize or hamper the reaching of the final agreement.

Taken literally, paragraph 3 does not limit de iure the sovereign powers of coastal States for the exploration and exploitation of their continental shelf/EEZ areas. ${ }^{43}$ In fact, as mentioned above, these substantial sovereign rights already inhere to coastal States by virtue of UNCLOS and customary international law. Rather, Articles 74(3) and 83(3) of UNCLOS introduce some procedural obligations which seem to restrain the exercise of these powers. ${ }^{44}$ These require States, firstly, to 'make every effort' to conclude 'provisional arrangements of practical nature' and, secondly, 'not to jeopardize or hamper the reaching of the final delimitation agreement' ${ }^{45}$ No explicit clarification is given regarding the kind of activities that would 'jeopardize or hamper' the final delimitation agreement and would thus be prohibited. Furthermore, the language used in this provision (ie 'shall make every effort') does not clarify the meaning of the procedural requirement to enter into provisional arrangement, ${ }^{46}$ in other words, the circumstances under which this obligation can be considered as fulfilled. However, all these aspects are crucial in understanding the legal rights and obligations of States with respect to oil and gas activities in disputed maritime areas.

\footnotetext{
43 Irini Papanicolopulu, 'Enforcement Actions in Contested Waters: The Legal Regime' (International Hydrographic Organization conference, Monaco, 25 October 2010) 4

<www.iho.int/mtg docs/com_wg/ABLOS/ABLOS_Conf6/S7P2-P.pdf> accessed 30 December 2015.

${ }^{44}$ Lagoni (n 3) 362.

${ }^{45}$ Virginia Commentary (n 27) 815, 984.

${ }^{46}$ Lagoni (n 3) 354.
} 
As a consequence, it is essential to examine the relevant international jurisprudence, academic literature and State practice on the application of Articles 74(3) and 83(3) of UNCLOS in order to ascertain their substantial scope of application and the extent to which they relate to oil and gas operations in disputed areas. Before doing so, however, it is useful to review the drafting history of Articles 74 and 83, particularly the negotiations that led to the formation of paragraph 3 of the said Articles, in order to understand how the rationale underpinning its inception evolved in the minds of UNCLOS drafters: from the early negotiations until its final construction.

\section{Drafting History of Articles 74(3) and 83(3) of UNCLOS}

It would be going too far to say that, during the negotiations at UNCLOS, no attention was paid to the question of provisional measures pending delimitation but it would be true to say that this issue was not a priority for UNCLOS drafters. This is because the greatest part of the discussions on delimitation centred upon the formation of a commonly acceptable delimitation rule or principle, ${ }^{47}$ rather than on interim solutions per se. Nonetheless, the intrinsic correlation between the problems arising from delimitation, clash of sovereign resource exploitation rights, protracted negotiating proceedings etc, and the need for some kind of solution in the interim prompted drafters to simultaneously address the two issues in the same provision. ${ }^{48}$ It would appear that, in the course of negotiations, two competing approaches were advanced by the delegations as interim solutions: a) the establishment of a moratorium with regards to all resource-exploitation activities in disputed areas and; b) the conclusion of 'provisional arrangements' pending final agreement on delimitation. As will be seen hereinafter, the final draft of Articles 74(3) and 83(3) constitutes a blend between these two elements, namely the 'restricting' element of prohibiting certain economic acts in the disputed areas and the 'incentive' element of provisional cooperative arrangements.

The first proposals to touch the issue of interim solutions were made by the Netherlands and Ireland during the second session of the Conference in $1974 .{ }^{49}$ Paragraph 2 of the Dutch proposal provided that, pending an agreement on delimitation, 'neither of the States is entitled

\footnotetext{
${ }^{47}$ Particularly the conflict between States which favoured equidistance (the pro-equidistance group) and those favouring a concept exclusively based on equity (pro-equity group); Edward D Brown, 'Delimitation of Offshore Areas-Hard Labour and Bitter Fruits at UNCLOS III' (1981) 5(3) MP 172, 179-180; Tanja (n 30) xvi.

${ }^{48}$ Lagoni (n 3) 348.

49 'Netherlands: Draft Article on Delimitation Between States with Opposite or Adjacent Coasts' UN Doc A/CONF 62/C2/L14 (1974), reproduced in Virginia Commentary (n 27) 803, 804; 'Ireland: Draft Article on Delimitation of Areas of Continental Shelf Between Neighbouring States' UN Doc A/CONF62/C2/L43 (1974), reproduced in Lagoni (n 3) 350.
} 
to establish its marine boundaries beyond the [median] line... ${ }^{50}$ Along the same basis, Ireland proposed that pending delimitation, 'no State is entitled to carry on exploration or exploitation activities in any areas which are claimed bona fide by any other State... ${ }^{51}$ Therefore, it can be seen that both the Dutch and the Irish proposals were couched in a rather prohibitive and preventive manner as their basic aim was to restrict all economic activities in the area of overlap.

Following a number of informal discussions, a new draft proposal was introduced by the Chairman of the Second Committee in 1976. ${ }^{52}$ This proposal, provided that, 'pending agreement or settlement, the States concerned shall make provisional arrangements... ${ }^{53}$ This was the first time the concept of 'provisional arrangements' had been presented as a possible interim solution during the discussions; it was at the expense, however, of the Dutch and Irish proposals. Despite the broad support this draft proposal seemed to have gathered initially, ${ }^{54}$ some States attempted to reintroduce the prohibitive language of the initial draft proposals. Spain for example, during the sixth session in 1977, suggested that, pending delimitation, 'the parties at dispute shall refrain from exercising their jurisdiction beyond the median or equidistance line unless they agree on alternative measures of mutual restraint' ${ }^{55}$ In fact, it appears that many States not only supported the Spanish proposal ${ }^{56}$ but also were strongly in favour of a 'moratorium against economic activities within the area under dispute' ${ }^{57}$ However, this was not regarded as being broadly acceptable ${ }^{58}$ as several other States continued to favour the more incentive language of the Chairman's proposal, as seen above. ${ }^{59}$ As a consequence, two diametrically opposing approaches emerged during the discussions: those which clearly aimed to restrain the activities of the interested States in the disputed area, ${ }^{60}$ and those concerned with the adoption of practical measures that could promote the economic utilisation of disputed areas, pending delimitation. ${ }^{61}$

\footnotetext{
50 'Netherlands: Draft Article' ibid; Given that any reference to the median or equidistance line, even as an interim solution, was not likely to receive much support from pro-equity States, the Dutch proposal was dismissed during the fourth session.

51 'Ireland: Draft Article' (n 49).

52 UNCLOS '49th Meeting of the Second Committee' (16 March 1976) Off Rec UNCLOS III, vol V, 153.

${ }^{53}$ UNCLOS Draft Articles 74(3) and 83(3) of UNCLOS (1979) 18 ILM 686.

54 '49th Meeting of the Second Committee' (n 52).

55 'Informal Proposal by Spain', reproduced in Virginia Commentary (n 27) 811.

56 Lagoni (n 3) 351, 352.

57 'Informal Proposal by Papua New Guinea', reproduced in Renate Platzoder (ed) Third United Nations Conference on the Law of the Sea: Documents Vol IV (Oceana Publications 1983) 406.

58 'Statement by the Chairman at the 28th Meeting of NG7' (12 Sept 1978), reproduced in Lagoni (n3) 352.

59 ibid.

${ }^{60}$ See: Netherland's and Ireland's draft proposals (n 49).

${ }^{61}$ Lagoni (n 3) 351.
} 
One year later, in 1979, after more than twenty-seven negotiating sessions had elapsed, a renewed proposal was submitted jointly by India, Iraq and Morocco. This provided that:

Pending agreement or settlement, the States concerned shall, in a spirit of co-operation, freely enter into provisional arrangements [and] shall refrain from activities or measures which may aggravate the situation or jeopardize the interests of either State... ${ }^{62}$

Interestingly, this provision was welcomed by the majority of delegates and following some minor changes in 1980, led to the formation of paragraph 3 of Articles 74 and 83 of UNCLOS as appears in $2016 .^{63}$

The review of the drafting history of UNCLOS reveals some important findings with respect to the purpose and objectives of Articles 74(3) and 83(3). It would appear that the conflict between different approaches on interim measures, as emerged during the negotiating sessions, led to the conclusion of a compromise formula which constituted a blend of two elements: the 'incentive' element of provisional arrangements and the 'restricting' element of prohibiting certain economic acts in the disputed region. It might thus be said that Articles 74(3) and 83(3) of UNCLOS have a twofold objective: while the first sentence aims to promote the adoption of practical interim measures towards the provisional economic exploitation of yet-to-be delimited areas, the second seeks to restrict the economic activities of the disputing States in the given area, pending the final settlement of their dispute. ${ }^{64}$ Such understanding of paragraph 3 of Articles 74 and 83 is consistent with the overall objective of UNCLOS, which according to its preamble, is 'to settle, in a spirit of mutual understanding and cooperation, all issues relating to the law of the sea' and 'a legal order for the seas and oceans which will facilitate ... the equitable and efficient utilization of their resources [with] due regard for the sovereignty of all States'.

The following section ascertains the extent to which the above provision relates to oil and gas operations in disputed areas. Given that Articles 74(3) and 83(3) of UNCLOS are basically a combination of two different elements, different considerations apply to each of the two elements. Accordingly, for the sake of coherence and analytical clarity, these will be separately examined further below.

\section{Obligation to 'Make Every Effort': Interpreted}

According to the first sentence of Articles 74(3) and 83(3) of UNCLOS, 'the States concerned, in a spirit of understanding and cooperation, shall make every effort to enter into provisional

\footnotetext{
62 'Informal Proposal by India, Iraq, and Morocco' (5 April 1979) reproduced in Platzoder (n 57) 448.

${ }^{63}$ Lagoni (n 3) 353.

64 This conclusion is also supported by the Virginia Commentary (n 27) 815, 984.
} 
arrangements... ${ }^{65}$ In light of its objectives, as seen above, this provision may be paraphrased as 'States concerned are required to make every effort to come to some agreement towards the economic exploitation of the disputed area, pending the final settlement of their dispute'. However, what does 'make every effort' mean in practice and how can an international court or tribunal determine whether a State has fulfilled or breached this obligation in the context of oil and gas activities in disputed waters?

Professor Lagoni suggested that the language used in paragraph 3, that 'every effort' should be conducted 'in a spirit of understanding and cooperation', echoes the traditional legal concept of good faith. ${ }^{66}$ Indeed, in the North Sea Continental Shelf Cases of 1969, the ICJ found that good faith 'is a principle which underlies all international relations, and which is moreover recognized in Article 33 of the Charter of the United Nations as one of the methods for the peaceful settlement of international disputes' ${ }^{67}$ Lagoni's view is also supported by the Fisheries Jurisdiction Case of 1974, where the ICJ held that both parties in dispute were 'under mutual obligations to undertake negotiations in good faith for the equitable solution of their differences concerning their respective rights in the areas [in question]' ${ }^{68}$ More recently, under the UNCLOS regime, the Guyana/Suriname Tribunal explained that the inclusion of the phrase 'in a spirit of understanding and cooperation' indicates 'the drafters' intent to require of the parties a conciliatory approach to negotiations, pursuant to which they would be prepared to make concessions in the pursuit of a provisional arrangement...' ${ }^{69}$ Thus, it is suggested that States are under a procedural duty to engage in 'meaningful' negotiations (ie not simply for the sake of negotiations but with a realistic view to arriving at an agreement). ${ }^{70}$ This will not be the case when, for example, 'either [State] insists upon its own position without contemplating any modification of it'. ${ }^{71}$

However, it is important to note that the procedural obligation to negotiate in good faith and seek provisional arrangements of practical nature does not imply an obligation to agree upon any provisional regime. ${ }^{72}$ Indeed, in the words of Lord McNair, there is a 'valid obligation upon the parties to negotiate in good faith, and a refusal to do so amounts to a breach of the

\footnotetext{
${ }^{65}$ Arts 74(3)(a) and 83(3)(a), UNCLOS.

${ }^{66}$ Lagoni (n 3) 355.

${ }^{67}$ North Sea CS Cases (n 10) para 86.

${ }^{68}$ Fisheries Jurisdiction Case (n 12) para 79.

69 Guyana/Suriname Case (Arbitral Tribunal) (Award) (2007) para 461, <www.pca-cpa.org/GuyanaSuriname\%20Award70f6.pdf?fil_id=664> accessed 30 December 2015.

${ }^{70}$ North Sea CS Cases (n 10) para 85.

71 ibid.

${ }^{72}$ North Sea CS Cases (n 10) para 87; Railway Traffic Case (Lithuania/Poland) (Advisory Opinion) [1931] 42 PCIJ 108, 116.
} 
obligation. But the obligation is not the same as an obligation to conclude a treaty or to accede to an existing treaty...' ${ }^{73}$ It can be concluded that States engaged in overlapping maritime claims are under a procedural obligation to engage in meaningful negotiations and make every possible effort to reach an agreement on the provisional economic exploitation of the area in question. $^{74}$

Turning now to the specific application of this obligation, it is noteworthy that the only case in which an international adjudicating body was called to determine the scope of application of Articles 74(3) and 83(3) of UNCLOS in the context of oil and gas operations was the Guyana/Suriname Arbitration of 2007. In this case, both parties claimed that the conduct of the other had breached Articles 74(3) and 83(3) of UNCLOS, namely, the obligation 'to make every effort to enter into provisional arrangements' and 'not to jeopardize or hamper the reaching of the final agreement'. With regard to the first obligation, Suriname claimed that Guyana had violated its duty to make every effort by 'persistently' demanding the former to allow CGX, Guyanese concessionaire, to conduct exploratory drilling in the disputed area. ${ }^{75}$ On its side, Guyana claimed that 'Suriname, both before and after the CGX incident, ${ }^{76}$ failed to make serious efforts to negotiate provisional arrangements. ${ }^{, 77}$

The Tribunal made a notable remark in stating that both States had breached their duty to make every effort to reach provisional arrangements, though for different reasons. As regards Suriname, the Tribunal found that it did not actively attempt to engage in meaningful discussions with Guyana as the latter had repeatedly requested. ${ }^{78}$ Rather, Suriname opted for a harder stance by resorting to self-help and threatening the CGX rig. ${ }^{79}$ As a consequence, it 'failed... in its duties under Articles 74(3) and 83(3) of the Convention'. ${ }^{80}$ Likewise, Guyana was found to have breached its duty to make every effort by not informing Suriname at an early stage of its concessionaire's plans to commence exploratory drilling in the disputed area. ${ }^{81}$ Most importantly, the Tribunal outlined a number of steps that Guyana should have made in order to satisfy the above obligation. These included inter alia 'seeking cooperation of

\footnotetext{
73 Arnold D McNair, The Law of Treaties (OUP 1961) 20.

74 Miyoshi (n 4) 12.

${ }^{75}$ Guyana/Suriname Case (n 69) para 471.

76 ibid para 150, 151. CGX Energy, a Canadian oil company, under a concession granted by Guyana, commenced exploratory drilling in the predefined concession area which was disputed by Suriname. Responding to this action, Suriname sent a naval warship to the area and ordered CGX to cease its activities.

77 ibid para 471 .

78 ibid paras 473-476.

79 ibid.

80 ibid para 476.

${ }^{81}$ ibid para 477 . The Tribunal found that public announcement in the Press was not sufficient.
} 
Suriname in undertaking the activities' and 'offering to share the results of the exploration and giving Suriname an opportunity to observe the activities' ${ }^{82}$

\section{Obligation of Mutual Restraint: Interpreted}

The second sentence of Articles 74(3) and 83(3) of UNCLOS requires States to abstain from any acts that would 'jeopardize or hamper' the final delimitation agreement. However, no express prohibition against certain petroleum activities, such as seismic surveys and exploratory or production drilling, is provided by this rule. The Virginia Commentary, one of the most important authorities on UNCLOS, does not clarify the scope of this restriction either. It simply observes that not all activities in the disputed area are prohibited but only those which would have the effect of 'harming or jeopardising' the final agreement. ${ }^{83}$

Arguably, any unilateral act, whether in the form of geophysical surveys, exploratory or production drilling, could potentially exacerbate the tension between the disputing parties and lead their negotiations on delimitation into a deadlock. However, an analysis of the relevant literature indicates that most commentators interpret this obligation lato sensu. ${ }^{84}$ More specifically, they argue that since Articles 74(3) and 83(3) of UNCLOS do not spell out which particular activities are prohibited, coastal States remain free to exercise their rights in the area so long as they do not irremediably deprive the other States concerned of their equally valid rights in the area in question. ${ }^{85}$ For example, it is often suggested that marine scientific research within the disputed area, even for the purpose of ascertaining the likelihood of hydrocarbonbearing accumulations, would not necessarily hamper the reaching of the final agreement on delimitation. ${ }^{86}$ Along the same line, some other commentators agree that coastal States are obliged to refrain only from the kind of actions that risk depriving other states of the gains they might have otherwise realised by exercising their sovereign right of exploitation. ${ }^{87}$ Obviously, this refers to the actual appropriation of natural resources from the areas under overlapping claims.

Interestingly, it seems that the central legal basis of this approach lies in the order of the ICJ on the Aegean Sea Continental Shelf Case of 1976 concerning Greece's request for the

\footnotetext{
82 ibid.

${ }^{83}$ Virginia Commentary (n 27) 815, 984.

${ }^{84}$ Fox and others (n 5) 3, 5; Beckman (n 16) 102-10; Miyoshi (n 4) 10-11; Ong (n 21) 798-799; Denis Tas, 'Oil and Gas in the East China Sea: Maritime Boundaries, Joint Development and the Rule of Capture' (2011) 29(2) IELR 48, 50-52.

${ }^{85}$ Miyoshi (n 4) 10.

${ }^{86}$ Lagoni (n 3) 366.

${ }^{87}$ Ong (n 21) 798.
} 
indication of interim measures of protection under Article 41 of the Statute of the ICJ ${ }^{88}$ Though UNCLOS came into force almost two decades later, this was the only case where an international court examined the legality of oil and gas operations in disputed waters, a fact which explains the unusual authority of this case on the matter, even under the UNCLOS regime. In this case, Greece requested the Court to determine the continental shelf boundary between the two States ${ }^{89}$ and, pending the final decision, to order, under Article 41 of the Statute of the ICJ, ${ }^{90}$ cessation of all Turkish exploration activities in the disputed areas of the Aegean Sea. ${ }^{91}$ In its application, Greece stressed that pending the delimitation of the area in question, any unauthorised exploration activities in the said area would be in breach of its 'sovereign and exclusive rights to explore and exploit its continental shelf and authorize scientific research respecting the continental shelf ${ }^{92}$ The Court rejected Greece's request on the basis that the 'effects of the alleged breach by Turkey would be reparable by appropriate means ${ }^{93}$ if the final judgment were to be delivered in favour of Greece. More specifically, the Court observed that the Turkish seismic exploration activities did not involve the establishment of any drilling installations or the actual appropriation of natural resources or any risk of physical damage to the seabed or subsoil of the area under dispute. ${ }^{94}$ In other words, the Court drew a distinction between exploratory activities of a transitory character, such as seismic surveys, and those that are likely to cause a permanent effect on the marine environment of the disputed areas, such as drilling and establishment of installations. ${ }^{95}$

Quite remarkably, the Guyana/Suriname Tribunal drew heavily upon the Aegean Sea Case, particularly when assessing the legality of unilateral exploratory drilling under Articles 74(3) and 83(3) of UNCLOS. More specifically, the Tribunal noted that:

\footnotetext{
${ }^{88}$ Provisional Measures, also known as Interim Measures of Protection, are not novel features of in international judicial proceedings, nor in international judicial proceedings involving the international uses of the oceans and the seas. The main rationale for these measures is that a party to a dispute before a court or tribunal is entitled to a reasonable assurance that the subject matter of the dispute will be safeguarded until the court of tribunal delivers its final verdict. It also serves as a protection mechanism as it prevents the disputing states from taking actions that could have the effect of rendering nugatory or of no effect the final decision to be rendered by the court or tribunal. For a discussion, see Natalie Klein, 'Provisional Measures and Provisional Arrangements in Maritime Boundary Disputes' (2006) 21(4) IJMCL 423.

${ }^{89}$ Greece's request on the merits was dismissed as the Court found itself without jurisdiction to entertain the dispute. See Aegean Sea Continental Shelf (Greece/Turkey) (Jurisdiction) [1978] ICJ Rep 3 para 109.

90 Art 41, ICJ Statute.

91 Aegean Sea CS Case (n 11) para 1.

92 ibid paras $1,2$.

${ }^{93}$ ibid para 33.

${ }^{94}$ ibid para 30.

${ }^{95}$ Miyoshi (n 4) 11.
} 
Activities that would meet the standard required for the indication of interim measures, in other words, activities that would justify the use of an exceptional power due to their potential to cause irreparable prejudice, would easily meet the lower threshold of hampering or jeopardising the reaching of a final agreement. ${ }^{96}$

In other words, the Guyana/Suriname Tribunal, in considering the application of Articles 74(3) and 83(3) of UNCLOS, aligned its reasoning with the criteria used by international courts and tribunals in assessing a request for interim measures of protection. This led the Tribunal to declare that it should not be permissible for a party to a dispute to undertake any unilateral drilling activity since this would prejudice the other party's rights in a permanent manner. ${ }^{97} \mathrm{On}$ the other hand, seismic surveys were considered, obiter dictum, as legally permissible due to their lower threshold of impact. ${ }^{98}$

\section{Unilateral Seismic Surveys in Disputed Waters}

Notwithstanding the important value of the Aegean Sea Case and Guyana/Suriname Case in assessing the legality of petroleum operations in disputed waters, not all the legal uncertainties surrounding the issue have been resolved. The view that certain activities, due to their manifestly prejudicial and irreparable effect, can justify the prescription of interim measures of protection, cannot in itself imply that any other petroleum activities in the disputed area should be permissible under international law. As a matter of fact, the present analysis finds that there are a number of arguments to support the proposition that, under the present framework of international law, unauthorised seismic surveys in disputed areas are illegal.

To begin with, despite the Guyana/Suriname Tribunal's ruling that seismic surveys in disputed waters should be permissible, ${ }^{99}$ one must not disregard the fact that none of the parties involved in the given case had challenged the legality of such activities. ${ }^{100}$ On the contrary, the historic background of this dispute indicates that both Guyana and Suriname had been authorising and conducting seismic activities in the disputed areas for over three decades ${ }^{101}$ without causing, however, any tensions in their relationship. As a result, it would not be unreasonable to argue that both countries had tacitly consented in a sense to each other's seismic activities in the disputed area. Indeed, the key incident that fuelled the dispute had

\footnotetext{
96 Guyana/Suriname Case (n 69) para 469.

97 ibid paras 467-477.

98 ibid para 469.

99 ibid para 481.

100 ibid para 471. Suriname contended that Guyana violated its obligation to make every effort not to hamper or jeopardise the reaching of a final agreement by allowing its concession holder to undertake exploratory drilling in the disputed waters.

101 ibid paras 147-148.
} 
nothing to do with seismic surveys, but with the intention of Guyana to undertake exploratory drilling. In light of these circumstances, the Guyana/Suriname Tribunal was essentially prompted to observe that unilateral seismic surveys, in the given case, neither prejudiced nor harmed the reaching of the final delimitation agreement as neither State seemed to be frustrated by the conduct of such operations. Indeed, in the words of the Tribunal:

Both Parties authorised concession holders to undertake seismic testing in disputed waters, and these activities did not give rise to objections from either side. In the circumstances at hand, the Tribunal does not consider that unilateral seismic testing is inconsistent with a party's obligation to make every effort not to jeopardise or hamper the reaching of a final agreement. ${ }^{102}$

Nonetheless, when reviewing the factual background of the Aegean Sea Case, for example, where Turkey's unauthorised seismic activities in the disputed area, and the fierce reaction of Greece, almost led the two States into an armed conflict, the legal treatment of unilateral seismic surveys cannot be the same. Indeed, in sharp contrast to the Guyana/Suriname Case, Turkey's unilateral seismic surveys in the Aegean Sea did have the effect of escalating the conflict so much that the task of delimitation became almost elusive. This is further illustrated by the fact that the most recent hydrocarbon exploration licenses granted by Turkey to its National Oil Company, TRAO, ${ }^{103}$ were also met with fierce diplomatic protests from Greece as some of the permit blocks were considered to be in areas of the Greek continental shelf. ${ }^{104}$ Even though Turkey rejected Greece's claim, ${ }^{105}$ no further seismic or drilling activities have been undertaken by Turkey, or Greece, in the Aegean Sea since then. ${ }^{106}$

Secondly, at the time of drafting this paper, the Special Chamber of the International Tribunal of the Law of the Sea (ITLOS) considered an application by Côte d'Ivoire asking Ghana to be ordered to 'suspend all oil exploration and exploitation operations under way' in the maritime area which was the subject of dispute between the parties. ${ }^{107}$ As it turns out, this

\footnotetext{
102 ibid para 481.

103 Turkish Council of Ministers, Decision 2012/2968 (Turkish Official Gazette, 27 April 2012)

${ }^{104}$ Greek Note Verbale (20 February 2013)

<http://www.un.org/depts/los/LEGISLATIONANDTREATIES/PDFFILES/communications/grc note 2002201 3 re tur.pdf $>$ accessed 6 April 2016.

105 Turkish Note Verbale (12 March 2013)

〈www.un.org/depts/los/LEGISLATIONANDTREATIES/STATEFILES/TUR.htm> accessed 30 December 2015.

${ }^{106}$ Yuhcel Acer, 'A Proposal for a Joint Maritime Development Regime in the Aegean Sea' (2006) 37(1) JMLC 49, 60.

${ }^{107}$ Dispute Concerning Delimitation of the Maritime Boundary between Ghana and Côte d'Ivoire in the Atlantic Ocean (Ghana/Côte d'Ivoire) (Provisional Measures, Order of 25 April 2015) <www.itlos.org/fileadmin/itlos/documents/cases/case_no.23_prov_meas/C23_Order_prov.measures_25.04.2015 _orig_Eng.pdf> accessed 30 December 2015.
} 
is the first time in the history of UNCLOS that a Special Chamber, formed by the ITLOS, has received a request for provisional measures and only the second time in international judicial practice that provisional measures have been sought against the undertaking of petroleum operations without consent in contested waters (the first one being the Aegean Sea Case of 1976). It is therefore worthwhile to review some of the central arguments in and the determination of this application by the Special Chamber.

In its application Côte d'Ivoire argued, inter alia, that the ongoing exploration and exploitation activities by Ghana caused a serious and irreversible harm to Côte d'Ivoire's sovereign exploration and exploitation rights. ${ }^{108}$ More specifically, Côte d'Ivoire argued that the conduct of geophysical investigations by Ghana constituted an infringement of the exclusive right of Côte d'Ivoire to conduct maritime scientific research, pursuant to Article 246(5) of UNCLOS, and its associated right to access, possess and control all confidential information relating to the exploration of the continental shelf. This, according to Côte d'Ivoire, formed an indispensable part of a coastal State's sovereign rights for the purpose of exploring the continental shelf and exploiting its natural resources as provided for in Article 77 of UNCLOS. ${ }^{109}$ Overall, Côte d'Ivoire emphasised that the actions of Ghana not only caused a serious and irreversible harm to Côte d'Ivoire's exclusive right to explore and exploit its natural resources but also irremediably deprived Côte d'Ivoire of its sovereign right to formulate and implement its national energy policy. This included its right to decide 'when, how and under what conditions the exploitation of these resources will take place, and even whether it should take place'. ${ }^{110}$

In its decision, the Special Chamber recognised, first of all, that drilling causes a 'permanent physical modification' of the area in dispute which no form of financial compensation or reparation can restore. ${ }^{111}$ Most importantly, it found that the acquisition and subsequent use of geological information of the disputed area would create a risk of 'irreversible prejudice to the rights of Côte d'Ivoire' should the Special Chamber, in its decision on the merits, find that Côte d'Ivoire has rights in all or any part of the disputed area. ${ }^{112}$

\footnotetext{
108 Ghana/Côte d'Ivoire (Provisional Measures) (Request of Côte d'Ivoire, 25 February 2015) para 19 <www.itlos.org/fileadmin/itlos/documents/cases/case_no.23_prov_meas/C23_Request_prov_measures_translati on Reg.pdf $>$ accessed 30 December 2015.

109 ibid para 30.

110 ibid para 38.

${ }^{111}$ Ghana/Côte d'Ivoire (n 107) paras 89-90, 'whatever its nature, any compensation awarded would never be able to restore the status quo ante in respect of the seabed and subsoil'.

112 ibid para 95.
} 
The Special Chamber went on to order Ghana to refrain from undertaking new drilling in the disputed area. Nonetheless, the Special Chamber did not order Ghana to suspend ongoing seismic surveys but rather to 'take all necessary steps to prevent information resulting from past, ongoing or future exploration activities conducted by Ghana... from being used in any way whatsoever to the detriment of Côte d'Ivoire'. ${ }^{113}$ In other words, it would seem that the Special Chamber acknowledged the irreparable infringement of Côte d'Ivoire's alleged exploration rights, caused by Ghana's unilateral geophysical surveys, but refrained from ordering the immediate suspension of such surveys.

What must be borne in mind in this discussion is that both the ICJ's order on the Aegean Sea Case of 1976 and the ITLOS order on the Ghana/Côte d'Ivoire Case of 2015 exclusively concerned the application of interim measures of protection. ${ }^{114}$ However, the law relating to interim measures of protection does not necessarily coincide in all respects with the obligations in Articles 74(3) and 83(3) of UNCLOS. As mentioned above, interim protection is an exceptional procedural right the essence of which lies in the preservation of the parties' alleged rights pendente litis. Key here is what actual harm a state might suffer pending the final judgment. Articles 83(3) and 74(3) of UNCLOS address the procedural duties of States to enter into meaningful negotiations in good faith and refrain from any unilateral actions that might have the effect of hampering the reaching of the final delimitation solution. The central condition here is actions that might have this effect.

Clearly, interim measures require a higher threshold of harm suffered by a State while awaiting the final verdict, compared to the condition stipulated by Articles 83(3) and 74(3) of UNCLOS. ${ }^{115}$ Indeed, whereas the indication or prescription of interim measures requires the 'risk of an irreparable prejudice to rights [of either party] in issue in the proceedings', ${ }^{116}$ Articles 83(3) and 74(3) simply refer to acts that might 'jeopardize or hamper' the final delimitation agreement. In fact, the power of the Court to order interim measures is an exceptional one $\mathrm{e}^{117}$ and presupposes that there is a serious and irreversible prejudice to the rights

\footnotetext{
113 ibid para 108(b), 'the exploration and exploitation activities, as planned by Ghana, may cause irreparable prejudice to the sovereign and exclusive rights invoked by Côte d'Ivoire in the continental shelf and superjacent waters of the disputed area, before a decision on the merits is given by the Special Chamber, and that the risk of such prejudice is imminent'.

114 Art 41, ICJ Statute; Art 290(1), UNCLOS.

115 Guyana/Suriname (n 69) para 469.

${ }^{116}$ Aegean Sea CS Case (n 11) paras 31-33; Malcolm N Shaw (ed), International Law (5th edn, CUP 2008) 10941095, citing the Great Belt Case (Finland/Denmark) (Provisional Measures) [1991] ICJ Rep 12, 17; Republic of the Congo/France (Provisional Measures) [2003] ICJ Rep 107 para 22 and the PulpMills Case (Argentina/Uruguay) (Provisional Measures) [2007] ICJ Rep 3 para 32.

${ }^{117}$ Aegean Sea CS Case (n 11) para 31.
} 
in issue which '[cannot] be erased by the payment of reparation or compensation to be ordered in later judgment on the merits'. ${ }^{118}$

Therefore, activities that give rise to a breach of the alleged rights, but are nonetheless reparable by appropriate means, such as compensation, ${ }^{119}$ do not warrant the indication of interim measures. ${ }^{120}$ As a matter of fact, Greece's request was dismissed, but not because the Court did not recognise that seismic surveys by Turkey violated Greece's exclusive rights of exploration. ${ }^{121}$ On the contrary, the Court recognised that Turkey's activities, without the consent of Greece, 'might, no doubt, raise a question of infringement of the latter's exclusive right of exploration'. ${ }^{122}$ Greece's request was dismissed because this clear violation of its substantial exploration rights was deemed as capable of reparation by appropriate means. Put differently, if Turkey's exploration activities had been conducted in an area that was subsequently found to be Greek continental shelf, Turkey would have committed a breach of Greece's sovereign rights for which appropriate reparation would have been required. ${ }^{123}$ The same holds true in the ITLOS case between Ghana and Côte d'Ivoire.

Consequently, even though unilateral seismic surveys in disputed areas do not necessarily cause an irreparable and irreversible harm that warrants interim protection, the conduct of such activities does, undoubtedly, infringe the other State's alleged right of exploring its continental shelf. This suggests that if the circumstances of the case demonstrate that the unconsented seismic exploration activities would have the effect of aggravating the dispute to the extent that discussions on final delimitation are adversely affected, ${ }^{124}$ they may well be considered as a breach of Articles 74(3) and 83(3) of UNCLOS.

Furthermore, it is worthwhile recalling that the Guyana/Suriname Tribunal established certain steps which Guyana, 'in a spirit of cooperation and understanding', ${ }^{125}$ should have taken before authorising any drilling operations in the disputed area, including, among others, offering to share the results of the exploration and giving Suriname an opportunity to monitor

\footnotetext{
118 Shigeru Oda, 'Provisional Measures: The Practice of the International Court of Justice' in Vaughan Lowe and Malgosia Fitzmaurice (eds), Fifty years of the International Court of Justice: Essays in Honour of Sir Robert Jennings (CUP 1996) 551.

119 Factory at Chorzow (Germany/Poland) (Merits) [1928] PCIJ SA No 17 para 48, where it was held that reparation must be able to eliminate all the consequences of the breach and restore the 'previously existing situation'.

${ }^{120}$ Oda (n 118) 541.

${ }^{121}$ Aegean Sea CS Case (n 11) para 33.

122 Oda (n 118) 551-552.

${ }^{123}$ Churchill and Ulfstein (n 6) 86.

124 Lagoni (n 3) 367.

${ }^{125}$ Guyana/Suriname Case (n 69) paras 477-478.
} 
ongoing drilling activities. ${ }^{126}$ Nonetheless, the Tribunal omitted to impose similar conditions for seismic exploration operations. This approach seems, however, rather questionable because, as with the obligation to seek provisional arrangements, the obligation of mutual restrain is also covered by the general legal requirement 'to make every effort in a spirit of understanding and cooperation' which, as mentioned earlier, echoes the fundamental legal principle of 'good faith'. Indeed, as the ICJ stated, this principle 'underlies all international relations'. ${ }^{127}$ Therefore, it would not be unreasonable to argue that any seismic tests in disputed areas, though unilateral, should be conducted in a 'spirit of understanding and cooperation', ie in good faith. As a result, the willingness of the initiating State to share the results of seismic exploration and allow the other State to monitor these activities would be a prerequisite to the fulfillment of this requirement. This argument is also consistent with analogous examples in international law. For instance, Article 3 of the 1974 Charter of Economic Rights and Duties of States establishes that, 'in the exploration of natural resources shared by two or more countries, each State must co-operate on the basis of a system of information and prior consultations...' ${ }^{128}$ Taking the above into consideration, it might be suggested that unilateral seismic tests in disputed waters should not be permissible, unless the party undertaking such activities is willing, in accordance with the principle of good faith, to share the results of exploration and allow the other State to monitor the whole procedure.

Finally, as mentioned above, one of the central arguments advanced by scholars to support that unilateral seismic activities in disputed waters are legally permissible is the fact that such activities, unlike drilling, cannot cause physical damage to the marine environment of the disputed area. On the contrary, several marine-scientific reports have concluded that the high volumes of acoustic energy, commonly released during seismic operations, ${ }^{129}$ may have an adverse environmental impact on the marine life ${ }^{130}$ and commercial fishing operations in or near the area in question. ${ }^{131}$ Directly related to this important consideration is the fact that,

\footnotetext{
126 ibid.

${ }^{127}$ North Sea CS Cases (n 10) para 86.

${ }^{128}$ UN GA Res 3281 (Charter of Economic Rights and Duties of States) (12 December 1974) 29th Session Supp 50 .

${ }^{129}$ Ingebret Gausland, 'Seismic Surveys Impact on Fish and Fisheries' (2003) 41 NOIA Rep 1, 5; Frank Jahn, Developments in Petroleum Science Vol 55: Hydrocarbon Exploration \& Production (Elsevier 2008) 28-33.

${ }^{130}$ Robert D McCauley and others, 'Marine Seismic Surveys - A Study of Environmental Implications' (2000) APPEA 692.

${ }^{131}$ Some studies conclude that catches were reduced by approximately 70 percent in the area of the seismic shooting, while significant effects had been observed in the entire area of 40x40nm. See: Arill Engås and others, 'Effects of Seismic Shooting on Local Abundance And Catch Rates of Cod And Haddock' (1996) 53 CJFAS 2238-2249; John R Skalski and others, 'Effects of Sounds From A Geophysical Survey Device on Catch-PerUnit-Effort' (1992) 49 CJFAS 1357-1365; For an opposite view, see: Gausland (n 129) 1.
} 
under present international law, all coastal States have the exclusive jurisdiction to adopt the necessary regulatory measures for the protection and preservation of the marine environment of their EEZs, ${ }^{132}$ as well as the exclusive right to explore and exploit their natural resources in accordance with their own environmental policies. ${ }^{133}$ Moreover, States have the exclusive jurisdiction to authorise scientific research, ${ }^{134}$ including seismic testing. ${ }^{135}$ To that end, coastal States have the right to object to and order the cessation of any marine scientific project associated with the exploration and exploitation of natural resources. ${ }^{136}$ Pursuant to the rights above, many coastal States have enabled regulations requiring prospective licensees to submit detailed environmental impact assessments (EIA) prior to the conduct of any seismic surveys, especially if such activities are likely to occur in areas sensitive to protected marine species or fisheries. ${ }^{137}$ The purpose of an EIA is to provide the coastal State with information on all the possible adverse impacts of the proposed activity and the measures through which the licensee purports to diminish or at least mitigate these risks to the lowest levels. ${ }^{138}$

Therefore, given that the enactment and exercise of these rights does not distinguish between delimited or disputed maritime areas, ${ }^{139}$ a State's ability to control, safeguard and apply its own environmental and regulatory policies on the marine environment of the EEZ and continental shelf areas appertaining to it should, in any case, be respected. Interestingly enough, this was one of the main arguments raised by Côte d'Ivoire in its latest application before the ITLOS in which it contended that Ghana's unilateral actions deprive Côte d'Ivoire of its 'right to select the oil companies to conduct exploration and exploitation operations and freely to determine the terms and conditions in its own best interest and in accordance with its own requirements with respect to oil and the environment'. ${ }^{140}$ As seen above, the Special

\footnotetext{
132 Art 56(b)(iii), UNCLOS.

133 Art 193, UNCLOS.

${ }^{134}$ Art 56(1)(b)(ii), UNCLOS.

135 Art 246(5)(a), UNCLOS; N Klein, Maritime Security and the Law of the Sea (OUP 2012) 99.

136 Art 253, UNCLOS.

137 For the United Kingdom, for instance, see: Offshore Petroleum Activities (Conservation of Habitats) Regulations 2001 (as amended, 2007); Offshore Petroleum Production and Pipelines (Assessment of Environmental Effects) Regulations 1999 (as amended, 2007); Joint Nature Conservation Committee, 'Guidelines for Minimising the Risk of Injury and Disturbance to Marine Mammals from Seismic Surveys' (August 2010) <www.ukooaenvironmentallegislation.co.uk/contents/topic files/offshore/seismic.htm> accessed 30 December 2015 .

${ }^{138}$ See, for example, Olga Shtepenko and others, 'Environmental Impact Assessment for 3D Seismic Survey' (July 2011) 76

<http://naalakkersuisut.gl/ /media/Nanoq/Files/Hearings/2012/Capricorn\%20Greenland\%20Exploration\%201\% 201td/endelig\%20eng.pdf $>$ accessed 30 December 2015.

${ }^{139}$ Vasco Becker-Weinberg, Joint Development of Hydrocarbon Deposits in the Law of the Sea (Springer 2014) 111-112.

${ }^{140}$ Ghana/ Côte d'Ivoire (n 107) paras 48, 61 and 94.
} 
Chamber acknowledged the existence of this right. ${ }^{141}$ As a consequence, there is enough evidence to prove that unauthorised seismic surveys in disputed waters override the sovereign right and exclusive jurisdiction of coastal States to regulate, control and safeguard the marine environment of their EEZ and continental shelf areas. Thus, none of the disputing States operates legitimately in undertaking such acts on a unilateral basis.

\section{IMPACT ON OIL AND GAS DEVELOPMENT}

The analysis above has demonstrated that, under present international law, States are obliged to refrain from undertaking any unilateral oil and gas activities in disputed waters should the latter prove to aggravate the dispute. What must be kept in mind, however, is that the legal considerations above are by no means of purely academic importance but may also have some serious practical implications on the development of the disputed natural resources.

First and foremost, it is noteworthy that in the absence of the necessary exploration activities, both in terms of seismic testing and exploratory drilling, the exact location and commercial quantity and quality of the area's hydrocarbon deposits cannot be ascertained. ${ }^{142}$ Notwithstanding that geophysical exploration techniques have been considerably improved during the past decades, ${ }^{143}$ exploration for new oil reservoirs still remains a high-risk activity. ${ }^{144}$ Indeed, according to petroleum geologists, even if seismic testing has taken place and the geological conditions of the area in question seem to be promising, ${ }^{145}$ only the drilling of an exploration well can indicate whether the relevant area is commercially exploitable or not. ${ }^{146}$ Moreover, drilling is critically important in terms of understanding the structural properties of the sea-bed for the purpose of constructing rigs and mooring buoys as foundations for platforms and for laying pipelines. ${ }^{147}$ However, as it has been previously explained, any kind of drilling in disputed areas without the consent of other interested State(s) is prohibited under international law and can be ceased through the application of provisional measures if the dispute is submitted before an international court or tribunal.

\footnotetext{
141 ibid.

142 Smith (n 14) 353.

$143 \mathrm{ibid}$, 'this has resulted in much more efficient pinpointing of prospective geological structures and a remarkably high rate of success in test drilling'.

${ }^{144}$ Paul D Newendorp and John R Schuyler (eds), Decision Analysis For Petroleum Exploration (2nd edn, Planning Press 2000) 327; Peter E Jones, Oil: A Practical Guide to the Economics of World Petroleum (Woodhead-Faulkner 1988) 107-118.

145 Stuart Archer, 'Presentation: Introduction to Petroleum Geology' (ExploHub, University of Aberdeen) (Date rendered: 24 April 2014). The so-called 'five steps to heaven': 1. source rock; 2. trap; 3. reservoir rock; 4. migration; and 5. Maturation.

146 Newendorp and Schuyler (n 144) 327, 387; Jahn (n 129) 25.

147 Smith (n 14) 355.
} 
That being the case, unless States agree on a boundary or enter a provisional cooperative arrangement, there would be only two options, or lines of action, available to the States concerned. The first option is that, pending the final settlement of the dispute, no unilateral action, including any form of drilling, is to be conducted by either State in the disputed area. Given, however, the significance of drilling in terms of new oil-field development, this option implies that the economic exploitation of the disputed area cannot go forward pending delimitation. The Aegean Sea is an example of this situation. There, Greece and Turkey agreed to refrain from any acts that would aggravate their dispute, including the authorisation and conduct of exploration activities in the disputed area. ${ }^{148}$ As a result, given that no delimitation agreement between the two States has been reached so far, the mineral potentials of the Aegean Sea remain to date unexploited. ${ }^{149}$

Another theoretically possible scenario is when either, or both, interested States choose to authorise and conduct exploratory drilling in the disputed areas, on a unilateral basis, despite the subsequent legal and political consequences that such arbitrary actions may entail. The recent incident between China and Vietnam in the disputed waters of the South China Sea represents an illustrative example of this scenario. More specifically, in May 2014, the Chinese State-owned China National Offshore Oil Company (CNOOC) commenced drilling operations near the disputed Paracel Islands, ${ }^{150} 120$ nautical miles off the coast of the Vietnamese mainland. ${ }^{151}$ In spite of strong protests by Vietnam, China refused to halt its drilling operations, stating that the rig was placed 'completely within the waters of China's Paracel Islands. ${ }^{152}$ The event received a great deal of publicity and triggered massive anti-Chinese riots within Vietnam, especially when the latter accused China of ramming and sinking a Vietnamese vessel which was at the vicinity of the rig. ${ }^{153}$ At least two people were killed during the riots, while many Chinese-run factories were burned to the ground, and several supply operations had to

\footnotetext{
${ }^{148}$ See Section C.4 of the present paper.

${ }^{149}$ Carl W Dundas, 'The Impact of Maritime Boundary Delimitation on the Development of Offshore Mineral Deposits' (1994) 20 (4) RP 273, 277; Acer (n 106) 60.

${ }^{150}$ Ernest Z Bower and Gregory B Poling, 'China-Vietnam Tensions High over Drilling Rig in Disputed Waters' (CSIS, 7 May 2014) <http://csis.org/publication/critical-questions-china-vietnam-tensions-high-over-drilling-rigdisputed-waters $>$ accessed 30 December 2015.

${ }^{151}$ Demetri Sevastopoulo, 'China Steps up Claims in Disputed Waters' Financial Times (29 May 2014 ) 13.

152 Nguyen P Linh, 'Vietnam Says Chinese Offshore Rig is Illegal: China disagrees' Reuters (5 May 2014).

${ }^{153}$ Divya Avasthy, 'Chinese Ship Sinks Vietnamese Fishing Vessel Near Controversial Oil Rig' International Business Times (27 May 2014).
} 
be halted for security reasons. ${ }^{154}$ The United States, a powerful actor in the area, called on China to 'freeze' its provocative actions and seek to diffuse tension in the area. ${ }^{155}$

In the light of the above, on 15 July 2014, China announced that it was withdrawing its 2 billion dollar rig from the disputed area, almost one and a half months before the end of the envisaged drilling schedule. ${ }^{156}$ Most importantly, in October 2015, China proposed joint maritime drills with South China Sea claimants as an attempt at 'jointly solving disputes and controlling risks'. ${ }^{157}$ It would appear that the dangerously escalating nationalistic overtones in the Vietnamese mainland and the risk of prejudicing its relations with other State actors in the area, such as the United States, prompted China to cease its drilling operations in the disputed South China Sea areas and turn to other cooperative and confidence-building mechanisms. It may thus be said that even though unilateral drilling remains a theoretically possible option, the huge geopolitical and legal risks it portends mean that such an option, at least from a commercial perspective, is highly unadvisable. ${ }^{158}$

At this point, it is also very important to note that the development of offshore oil and gas deposits is, besides being a high-risk activity, an extremely expensive task as well. ${ }^{159} \mathrm{By}$ way of example, a modern 3D seismic vessel costs around 100 million USD, ${ }^{160}$ seismic data acquisition and processing can be as high as 0.5 million USD for a small area of 100 square kilometres, ${ }^{161}$ whilst the cost of drilling an offshore well can be over 50 million USD. ${ }^{162}$ Given the huge capital outlays involved in offshore petroleum development, States often rely on the funds and technical expertise of international oil and gas companies to develop their indigenous hydrocarbon resources. ${ }^{163}$ The first step an international oil company will take in deciding what regions of the world are promising is evaluating and ascertaining the geological, technical, political, fiscal, and environmental conditions of the given regions. ${ }^{164}$ Even if geological

\footnotetext{
${ }^{154}$ Michael Peel, 'Ready to Rumble' Financial Times (29 May 2014) 13.

155 Jane Perlez, 'Chinese Oil Rig Near Vietnam to Be Moved' New York Times (15 July 2014); Demetri Sevastopulo, 'US Warships to Challenge Chinese Claims in South China Sea' Financial Times (8 October 2015). 156 Perlez (n 155).

157 'China Suggests Joint South China Sea Drills with Asean' BBC News Asia (16 October 2015) <www.bbc.co.uk/news/world-asia-34546820> accessed 02 January 2015.

${ }_{158}$ According to a spokesman of the Vietnamese Legislature, the Vietnamese Government considered filing an international lawsuit against China. See: Thanh Nien, 'Vietnam Preparing to Sue China over Oil Rig: House Speaker' Thanhnien News (25 May 2014). No such step has been taken by Vietnam to date.

${ }^{159}$ Mark Hammerson, Upstream Oil and Gas (Globe Law and Business 2011) 174; Fox and others (n 5) 39.

${ }^{160}$ Roland Festor, 'Investments and Costs' in Denis Babusiaux (ed), Oil and Gas Exploration and Production (Technip 2007) 130.

161 ibid 129-132.

162 ibid.

${ }^{163}$ Ralf Emmers, Resource Management and Contested Territories in East Asia (Palgrave 2013) 83.

164 Jahn (n 129) 1-4.
} 
conditions indicate the likelihood of technically recoverable hydrocarbons, political and economic conditions, such as government and regulatory stability, must also be favourable for the successful commercialisation of the said reserves. ${ }^{165}$ Oil companies must have a firm casescenario in place that the potential revenues from future production justify present investments in exploration. ${ }^{166}$

Regions with undefined or disputed maritime borders are characterised by excessive territorial uncertainty. Specifically, there is uncertainty as to which of the two, or more, claimants holds exclusive rights and authority over petroleum operations in the area(s) in question. For oil companies, the corresponding effect of this uncertainty is the creation of moderate political risks: that is, the probability that the goals of their investment can be adversely affected by future changes in the political and national investment regime. ${ }^{167}$ As Lax notes, whereas uncertainty concerns a 'subjective potentiality of loss' based on existing political and economic conditions, a political risk is a 'measurable probability of loss' resulting from a change in those conditions. ${ }^{168}$ In that sense, oil companies cannot predict what the final outcome of the dispute will be, nor can they influence the adjudicating body's decision. However, they are perfectly aware that the dispute may lead to a change of jurisdiction in which case their exploration and exploitation rights will not be guaranteed. ${ }^{169}$ According to some petroleum experts, 'an uncertain or disputed international boundary is an additional risk factor' the essence of which lies in the 'uncertainty with regard to the geographic scope of a concession area'. ${ }^{170}$ Indeed, any company that knowingly decides to undertake investments in a disputed area could be left without a secure title to its investment if the relevant concession area is ultimately determined to belong to a neighbouring state, or if the latter seeks the termination of the ongoing petroleum operations through an injunction, pending the judicial settlement of the dispute. As the British Institute of International and Comparative Law (BIICL) explained, 'a secure investment framework including legal security of tenure is a sine qua non for the development [of offshore oil and gas deposits]'. ${ }^{171}$ However, none of these vital investment

\footnotetext{
165 ibid.

166 Howard L Lax, Political Risk in the International Oil and Gas Industry (Springer 1983) 8-9.

${ }^{167}$ For a discussion, see Martin Pratt and Derek Smith, How to Deal with Maritime Boundary Uncertainty in Oil and Gas Exploration and Production Areas (AIPN 2007).

${ }^{168} \operatorname{Lax}$ (n 166) 8-9, 'a risk implies the ability to calculate probabilities and therefore to protect against and manage future contingencies, whereas uncertainty does not'.

169 Paul M Blyschak, 'Offshore Oil and Gas Projects Amid Maritime Border Disputes: Applicable Law' (2013) 6(3) JWELB 210, 211.

${ }^{170}$ Gerard H Blake and others (eds), Boundaries and Energy: Problems and Prospects (Kluwer Law International 1998) 25-26; Lagoni (n 3) 361, notes that 'a consortium is hardly likely to explore an area without having at least a fair chance of getting a concession to exploit it afterwards if oil and gas are found'.

${ }^{171}$ Fox and others (n 5) 39.
} 
conditions (ie regional stability, legal security of tenure, etc) can be guaranteed in areas subject to the overlapping sovereignty of two, or more, States.

Last but not least, one must not fail to consider the reputational damage an oil company may face by engaging in unilateral petroleum activities in disputed waters. ${ }^{172}$ A recent example of this situation can be observed in the maritime boundary confrontation between Turkey and the Republic of Cyprus in the Eastern Mediterranean Sea. ${ }^{173}$ There, the Italian oil company ENI, under a concession granted by Cyprus, proceeded to conduct a number of exploration activities in areas off the coast of Cyprus which were disputed by Turkey. ${ }^{174}$ In retaliation for ENI's operations in Cyprus, Turkey suspended all its ongoing projects with ENI, including the construction of a major crude oil pipeline from the Baltic Sea to the Mediterranean. ${ }^{175}$ Likewise, returning to the Sino-Vietnamese conflict discussed above, it would appear that in 2008, the Chinese Government warned a major oil company, ExxonMobil, to refrain from investing in the disputed waters off the coasts of Vietnam and near the Paracel Islands, otherwise 'its future business interests on the [Chinese] mainland could be at risk'. ${ }^{176}$

\section{E. CONCLUSION}

The preceding discussion has demonstrated that, with respect to the economic development of disputed maritime areas, coastal States are under a procedural duty to negotiate in good faith with a view to reaching some form of cooperative joint agreement pending the final settlement of their boundaries. Simultaneously, coastal States are under a procedural obligation to refrain from any unilateral petroleum activities in disputed areas, particularly if the conduct of such activities proves to aggravate their dispute. Furthermore, the evidence from case law and State practice as presented above supports the idea that maritime delimitation disputes can have a catastrophic impact on the development of disputed offshore natural resources. Drilling is the only pragmatic means to identify petroleum deposits and international oil companies are not keen on investing their risk capital and resources in politically unsettled situations. The procedural obligations imposed on disputing States under UNCLOS, particularly to refrain from unilateral economic activities, combined with the moderate political risks that

\footnotetext{
172 When authorised by one of the States concerned.

${ }^{173}$ For a discussion, see Daniel Arbell and others, 'Politics Trump Economics in the Complex Game of Eastern Mediterranean Hydrocarbons’ Brookings (20 December 2013) <www.brookings.edu/research/opinions/2013/12/20-politics-trump-economics-eastern-mediterraneanhydrocarbons $>$ accessed 30 December 2015.

174 ibid.

175 Daren Butler, ‘Turkey Suspends Projects With ENI Over Cyprus Activities' Reuters (27 March 2013).

${ }^{176}$ Greg Torode, 'Oil Giant Is Warned Over Vietnam Deal' South China Morning Post (20 July 2009).
} 
characterise disputed regions, largely because of their undefined territorial status, mean that large offshore oil and gas investors most often tend to avoid venturing into those areas. Ultimately, in the absence of an agreed boundary, only provisional interstate cooperation, such as joint exploration and development, can enable disputing parties to facilitate investments and realise the economic potentials of disputed areas. ${ }^{177}$

${ }^{177}$ Dundas (n 149) 277. 